\title{
Professional Ethics of Chinese Judges
}

A rising issue in the landscape of judicial practice

\section{Yuwen Li}

\section{OpenEdition}

\section{Journals}

Édition électronique

URL : http://journals.openedition.org/chinaperspectives/274

DOI : $10.4000 /$ chinaperspectives. 274

ISSN : 1996-4617

Éditeur

Centre d'étude français sur la Chine contemporaine

Édition imprimée

Date de publication : 1 juin 2003

ISSN : 2070-3449

\section{Référence électronique}

Yuwen Li, «Professional Ethics of Chinese Judges », China Perspectives [En ligne], 47 | May-june 2003, mis en ligne le 19 septembre 2006, consulté le 28 octobre 2019. URL : http://journals.openedition.org/ chinaperspectives/274; DOI : 10.4000/chinaperspectives.274

Ce document a été généré automatiquement le 28 octobre 2019.

(c) All rights reserved 


\section{Professional Ethics of Chinese Judges}

A rising issue in the landscape of judicial practice

\section{Yuwen Li}

1 On October 18th 2001, the Chinese Supreme People's Court issued the Code of Conduct for Judges in the PRC (the Code) ${ }^{1}$, which makes China one of the few countries in the world with a specific code of conduct for the judiciary. Following the amendment of the Law on Judges in June 2001, the introduction of the Code was an important event, and one that illustrated the continued efforts of the Supreme People's Court (SPC) to improve professionalism among judges.

2 The promulgation of the code can be looked at from two angles. Inwardly, it is a natural development in court reforms that began more than a decade ago. In the 1980s court reform started with a change in the trial mechanism of local courts to overcome the inability of the courts to handle the increased number of civil and economic cases resulting from the economic reforms ${ }^{2}$. Since then the SPC has taken the leading role in furthering and widening the reforms, to cover trial proceedings, the enforcement of judgments, the reorganisation of the internal bodies of the court, the management of judges, etc. These changes relate to the trial system, institutional reorganisation, and the granting of more autonomy to judges. It is becoming obvious that reform measures cannot be efficiently implemented without an improvement in the professional quality of judges. Judicial professionalism demands both the competence of judges to adjudicate cases according to law and to a high standard of morality and conduct to ensure that judges are (and are seen to be) fair and impartial.

Outwardly, the emphasis on judicial ethics is a positive response to public opinion. In recent years, although the Chinese courts are handling more and more cases and their role in society is now more prominent, dissatisfaction with and complaints about the work of the courts has also increased considerably. The delay in the handling of cases, the lack of transparency of judicial proceedings, widespread judicial misconduct, judicial corruption, and the slow, disorganised and inefficient reform measures have all generated mounting discontent. Some Chinese commentators have concluded that 
there is widespread distrust of the judiciary by the public as a whole. ${ }^{3}$ Their critique has pointed out that judicial power (as a public power) in China is now being privatised, personalised and localised.

4 The term "ethics" usually refers to a collection of rules or standards of conduct expected of a particular professional group, such as doctors, solicitors or judges. It requires that any member of such a group who departs from those ethical standards to a striking degree will be excluded from his profession. It has been argued, "the ethical standards required from judges call for perhaps the highest and most rigorous standards, sacrifices and disciplines of any profession in the community"4.

There are different ways of dealing with the issue of judicial ethics. Some countries address the issue in general law. For instance, Germany has a judiciary act which contains certain articles dealing with judges' conduct, but no detailed standards ${ }^{5}$. On the other hand, some countries have a special code of conduct for judges, such as the USA, Canada and Italy 6 .

6 In China, the Law on Judges, the Organic Law of the Courts, and the Criminal Law contain provisions relevant to judicial ethics. The promulgation of the Code could be evaluated as a further step in the standardising of judges' conduct. The Code contains 50 articles, divided under the headings of six essential principles, namely: judicial impartiality, judicial efficiency, integrity of judges, judicial decorum, the selfimprovement of judges and the restriction of extra-judicial activities. These general principles are similar to those provided in the US Code ${ }^{7}$; however, the detailed rules under each principle reflect Chinese characteristics. This article will first analyse the principles and standards of the Code by providing some general information on the current problems facing the Chinese judiciary. It will then discuss various aspects and obstacles to the implementation of the Code. Most information given in this article is based on an overview of Chinese and English legal literature, and, to certain extent, on the author's interviews with Chinese judges, scholars and lawyers.

Principle 1: ensuring judicial impartiality

7 Seventeen of the 50 articles of the Code are devoted to judicial impartiality, which covers four aspects: substantive justice and procedural justice; independence; neutrality; and non-discrimination.

Substantive justice and procedural justice

8 Article 1 of the Code requires that, when exercising adjudicative power, judges should aim for both substantive and procedural justice and such justice should be shown by a judge's conduct in and outside the courtroom to avoid any reasonable public doubts about judicial impartiality.

9 Chinese legal tradition emphasised substantive justice while it neglected procedural justice. Even though, since the 1980s, laws on criminal, civil and administrative procedure have established and strengthened the procedural system, they "still exhibit features of Maoist-socialist law-flexibility, inexactness, and preoccupation with

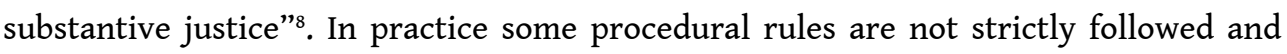
some are even seriously violated by some courts ${ }^{9}$. Violations of procedural rules are mainly reflected in four aspects as described by a Chinese scholar ${ }^{10}$. First, obvious abuse of procedural laws in handling cases, such as fighting for jurisdiction of a case while ignoring provisions of jurisdiction; refusing to file a case under the court's jurisdiction or unduly delaying making the decision as to whether a case can be filed; breach of rules on collection of evidence by meeting one party and his lawyer, or even travelling, 
dining, and staying at the same hotel with the party (san tong, in which the costs are paid by the party); breach of the principle that the courts, the prosecution office and the public security organs should divide responsibility and inspect each other, by exercising a system of "jointly handled cases" (lianhe ban'an); violation of the supervision provision between higher and lower courts by "communication in advance"; violation of mediation rules by forcing parties to accept mediation; breach of the open trial system; and willingly delaying the handling of cases, causing a violation of the time limit for conclusion of the trial of a case. Secondly, not strictly following legal procedure. For instance, having made a decision on a case before the case comes to trial, making the trial a mere formality; people's assessors merely accompanying the judge, but not being involving substantively in handling a case, rendering the collegiate system a ceremony; not giving sufficient time for the parties and their lawyers to prepare their defence; and not providing legal reasoning in judgments. Thirdly, improperly modified legal procedure, for example, the chief of the department and the president of a court approving judgment unilaterally thus undermining the competence of the collegiate bench provided by law; and, for difficult cases the lower court applying instructions from a higher court violating the jurisdiction system provided by law. Fourthly, various procedural rights enjoyed by parties to a case are sometimes not respected or parties are deprived of these rights. Such rights include having a lawyer and agent; a request for an open trial and a published judgment; a request for reasonable time to prepare a defence; requiring judges who have a personal interest in a case to withdraw; a request for mediation and a voluntarily reached mediation agreement; and requiring judges to pay cautious attention to one's opinions during a trial.

It is small wonder then, that a saying in goes China that procedural rules are hard law for the parties but soft law for the courts and judges ${ }^{11}$.

11 It should be noted that the most serious violations of procedural rules occur in the pretrial phase during detention. It is not exceptional that suspects have no timely access to a defence lawyer and that lawyers meet obstacles in the gathering and investigation of evidence ${ }^{12}$. Police intimidation and brutality are also not unusual. A distinguished Chinese legal expert, He Weifang, points out that from Chinese media reports we know that occasionally suspects are tortured, and we also know that often the cases exposed by the media are particularly serious, where death has resulted, such as the case reported by the Southern Weekend on April $24^{\text {th }} 1998$ under the title 'A Death Case from the Public Security office ${ }^{13}$. It is in fact not difficult to find information in Chinese newspapers and legal journals on the torture or illegal treatment of suspects and even non-suspects by the police. For instance, in December 2001 the journal "Fazhi $y u$ xinwen" (Law and News) reported a case where policemen tortured two murder suspects and forced them to write affidavits causing a six-year long and unjust case against the suspects, following which one suspect received three death penalties. Fortunately, he escaped execution following retrial ${ }^{14}$. In another case, a policeman spent hours alone with a 17-year old country girl in a police station to persuade her to confess to having had sexual relationships, which led the girl to commit suicide ${ }^{15}$. According to an official statistic, there were 19,504 cases of human rights violations by police from 1991 to 1993, approximately 7,000 annually ${ }^{16}$. Instances of judges beating up defendants are also reported. For instance, two judges in a county court in Hubei province, in carrying 
out a summons for detention, had a quarrel with the defendant; the judges beat the defendant leaving him with serious injuries ${ }^{17}$.

In recent years, Chinese lawyers have been active supporters of procedural justice, advocating that, when serious procedural errors are found to have occurred, the release of a suspect is less harmful to society than an open violation of procedural law. This is because the recognition of a violation of a person's procedural rights amounts to the recognition of an illegal act by the judicial organs. If the judicial organs do not take procedural law seriously, they may infringe citizens' rights at will, which causes extensive damage to society. Moreover, violation of procedure is in essence a violation of human rights: "Someone who is involved in the violation of human rights and in illegal acts has an ulterior motive and thus is guilty of using state power for private interests" ${ }^{18}$. Such views need to acquire sufficient attention and support from the Chinese judiciary. In addition, one has to regret that the lack of effective provisions in Chinese law on the legal consequences of the violation of procedural rules, which results in violations not being able to be dealt with promptly ${ }^{19}$. Jing Hanchao, Deputy President of the Higher Court in Hebei province, once pointed out that despite the prohibition by law, torture cannot be prevented in practice mainly because evidence obtained under torture is still being used by judicial organs. If any evidence obtained by torture were absolutely excluded by the courts, then the torture problem would be resolved ${ }^{20}$.

Independence

Judicial independence, as the precondition for judicial impartiality, is a fundamental principle codified by law in most countries and is recognised by international conventions. According to international standards, judicial independence includes both the independence of courts and the independence of judges ${ }^{21}$. Under the current Chinese legal framework, only the independence of courts is recognised, though one could argue strongly that, in practice, such independence is hampered by various borders. The independence of judges as a body as well as individuals remains unclear in law.

14 There are a number of articles in English dealing with the troublesome issue of judicial independence in China ${ }^{22}$. One could argue that many judicial problems and crises derive from the lack of such independence. It is a fundamental fault in the Chinese system and can only be resolved with determined political will. Indeed, in recent years the Chinese government has gradually loosened its control on the economic sector so as to allow the transition to a market economy. The success of the Chinese economy over the last twenty years has proved the corrective effect of this policy. Similarly, promotion of an independent judiciary could in the long run well facilitate China's economic prosperity, social stability and progress, as well as political democracy. All these factors will in the end strengthen the authority and public trust of the government.

Currently, interference with judicial work mainly comes from two sources. Firstly, Party and government intervention, such as Party and government officials giving instructions to judges in an individual case; political and legal committees (organs of the Party at all levels) discussing significant cases; and the police, the prosecutor's office and the court sometimes deciding cases jointly. Even though there is no legal basis for such practices, they exist as the government's habitual way of treating the courts. The second source of intervention in judicial processes is individual intervention, which may come from those who possess administrative power or those 
who have money. Since Chinese courts, especially local courts, depend on local government for financial support and the appointment and promotion of judges, they are particularly weak in facing up to government interference. This has resulted in a dramatic increase in local judicial protectionism. The Supreme People's Court recognised that "the emergence and extension of local judicial protectionism has seriously threatened the integrity and authority of our country's socialist legal system" ${ }^{23}$. One Chinese commentator has summarised local judicial protectionism into six facets ${ }^{24}$ :

16 1) Some courts compete for jurisdiction by handling cases they should not handle in order to get the advantage in cases involving property or profit;

2) some courts refuse to file cases or postpone the hearing of cases so as to assist local parties;

3) some courts wilfully treat economic crimes as economic disputes so as to protect a local party's illegal gains;

19 4) some courts inappropriately apply coercive measures so as to be the first to control assets;

5) some courts misinterpret the law, distort the facts, and make unfair judgments in favour of the local party;

6) some courts make it difficult for non-local judgments to be enforced.

Despite the serious difficulties and obstacles to judicial independence, the Code of Conduct for Chinese Judges cannot avoid the issue because of its crucial nature for the judiciary. The Code intends to remind judges to uphold the principle of independence in adjudication by stressing that: they are not subject to interference by administrative organs, social organs or individuals (Art. 2); they should refuse parties, or anybody using "networking" in an attempt to influence them (Art. 4); and they should think independently, judging autonomously and have the courage to reach the decision which they believe to be correct (Art. 7). However, in view of these types of interference, which are deeply rooted in the legal and political systems, one can imagine how it must be for judges to follow the Code's provisions closely. Recently, the Chinese newspaper "Southern Weekend" reported that a judge, Jia Tingrun, who was the President of Lulong County Court in Hebei Province, suffered unfair treatment because he refused to try a case according to the local government's instruction. In March 1994, he had to deal with a "tough case" concerning a manager of a private business who was accused of "embezzlement and misappropriation of co-operative funds" by the local government. Judge Jia discovered that the manager was merely a farmer and therefore, under the law, could not be charged with such a crime. His view was rejected by the local government. The Qinhuangdao Municipal Intermediate Court (which is a level higher than the county court) instructed Judge Jia just to follow the local government's instruction. The local Communist Party officials also pressured Judge Jia to resolve the case soon. However, Judge Jia did not submit to these pressures. In August 1994, the local government announced the decision by the Qinhuangdao Party Committee to remove Judge Jia from the office of President of the County Court. A few days later he was dismissed from the Court and was transferred to the county judicial bureau as an ordinary cadre. His salary was cut from 620 yuan to 350 yuan and his administrative ranking was moved down two levels. Moreover, the Qinhuangdao Party Committee and the Lulong County Party Committee organised several 
investigation groups to look for financial problems concerning Judge Jia, but they revealed nothing. After the removal of Judge Jia, the manager was sentenced to seven years imprisonment as the local government had wanted. This wrongful judgment was only corrected in 2001 after years of effort on the part of a few lawyers. Consequently, Judge Jia's bitter experience became known ${ }^{25}$. This case shows the vulnerability of the judge and president of a local court in facing the powerful governmental and Party influence.

Aside from external interference with the courts' and judges' independence, the independence of individual judges within Chinese courts is also jeopardised by colleagues trying to influence one another. To correct this practice, Article 13 of the Code requires a judge to respect the exercise of independence in adjudication by other judges. More precisely, a judge may not comment on cases being handled by other judges and may not give suggestions or opinions on cases in which his interests are involved; he may not ask about or interfere in cases that are being handled by lower courts; and he may not offer personal opinions to the higher court for cases at second instance. Article 14 requires further that a judge, except in exercising his adjudication or management duty, may not ask for information about cases handled by other judges. A judge may not reveal or provide information to the parties or their representatives concerning the hearing of the case and ways to contact the judges in charge, nor may he introduce the judges to the parties concerned. These standards on judges' relationships within a court seem attainable if courts and judges take them seriously.

In addition, the Code specifically requires that judges should not be improperly influenced by the media and public opinion and should not give comments in public or to the media, which might undermine the seriousness and authority of a valid judgment (Art. 16). In recent years a positive development in China has been more media coverage of court work, in particular discussions of effective judgments. Both national and local TV stations broadcast regular programmes revealing how the law is working in the courts. The media try to invite more judges to comment on controversial cases and public ratings for such programmes are high. This development enhances people's legal education and is conducive to the promotion of the public's right to information. But, inconsistent opinions of individual judges may also cause people to doubt the integrity and fairness of the judiciary as a whole, and a judge may also be under pressure to make a certain judgment. The code intends to find a balance between the independence of the judge and the authority of the judiciary as a whole. It is internationally recognised that:

"Sustaining support for judicial independence in this age of political and media scrutiny is a weighty challenge... central to meeting that challenge is a judiciary that recognises the importance of communicating with the public in ways that will enhance their legitimacy and justify their independence" ${ }^{26}$.

As far as the relationship between judges and the media is concerned, Chinese judges face the same dilemma as judges in other countries; moreover, they suffer from an extreme lack of experience in dealing with the media. It seems advisable that some concrete measures need to be introduced to reduce the risk involved where individual judges deal with the media. For instance, each court could have one or two press judges who are responsible for all of the court's contact with the media, including newspapers, radio, TV, etc.

Neutrality 
26 Article 11 of the Code obliges judges to remain neutral in their handling of cases. It requires that before a judgment is announced, a judge should not reveal his opinion or attitude by language, expression or conduct and a judge should mediate cases in accordance with law and be cautious with language and conduct so as to avoid generating any reasonable doubt as to his impartiality. Article 5 stresses that judges should not take improper measures to force parties to withdraw a case or accept mediation against their will. Article 8 states that during the process of a lawsuit judges should not meet a party or his representative privately. There are at least two main problems relating to the neutrality of judges. One concerns mediation, and the other relates to ex parte contact.

As to mediation, it has played a significant role in the history of the communist judicial system, which resulted in the realisation of mediation as the core model of handling civil and economic cases while adjudication was neglected. Since the end of the 1970s mediation has undergone some changes ${ }^{27}$. The 1982 Civil Procedure Law (CPL) amended the policy of "mediation as core" into the principle of "emphasising mediation". The 1991 revised CPL further weakened it to "carrying out lawful mediation based on voluntarism and law". However, under the current civil, criminal and administrative procedure laws mediation is still regarded as a significant step before adjudication ${ }^{28}$. According to critics $^{29}$ Chinese judges habitually prefer recourse to mediation, and this was not only because of the law and policy influence in the past but also due to their own interests. Compared to adjudication, mediation could bring judges some advantages: it enables judges to handle more cases at the same time; generally speaking, mediation is a speedy way of ending a case; and it is rather flexible in process. As to writing a legal document, some cases do not require a formal mediation agreement. Furthermore, for those cases where a mediation agreement is needed, such an agreement need only contain the litigation claims, facts and mediation results, unlike a judgment which has to provide detailed arguments on the recognition of facts and the application of laws. Since many courts exercise a system of evaluating a judge's work according to the number of cases the judge has handled, and linking this directly with the economic value of a judge, this inevitably encourages judges to choose mediation as a fast-result model to deal with cases. In addition, mediation enables judges to avoid making difficult decisions. In practice under certain circumstances, such as insufficient evidence to reach a certain decision, lack of clear legal provision, or the law being too vague and general, it may be very difficult for judges to make judgments. This contrasts with mediation agreements where, so long as the parties concerned reach a compromise, there is no need to state which legal provisions form the basis of the agreement. Furthermore, there is little risk to judges in mediation since no appeal or retrial procedure is possible. If a judgment is changed by the higher court on appeal, the original judgment is deemed wrong and subsequently the judge who made the judgment is considered to have made a wrong decision.

Taking into account all these benefits, one can understand why judges prefer mediation. However, such a preference also results in serious problems of coercion and non-voluntary mediation, and mediation without principles $^{30}$. Moreover, some increasingly grave judicial problems, such as judicial corruption, abuse of judicial power and local judicial protectionism, are to various degrees linked with the mediation system ${ }^{31}$. It is observed that: "A variety of sources suggest that in practice judicial mediation raises serious issues of legality" 32 . 

judge's office or home, restaurant, hotel, bar or other place of entertainment ${ }^{35}$. A party or his lawyer uses such opportunities not only to try to influence the judge's opinion on a case but also to give the judge gifts or bribe him. The problem of ex parte contact is two-sided. On the one hand it is closely linked with the general environment in China that too often if one wants something to be done one has to use "personal relationships". People feel more secure if they have access to a judge outside the court. This phenomenon itself is a repercussion of the lack of the rule of law. On the other hand some judges, for various reasons, accept the invitations of parties to lawsuits. Over the years this "give and take" practice has developed into a vicious circle that once a lawsuit has emerged, all parties try to establish contact with the judges. Winning a case becomes a matter of who has strong relations with the judges or courts (da guansi shi da guanxi). and professional rules. In 2000, the Supreme People's Court issued the Several Provisions Concerning the Strict Application of the Withdrawal System by Judges ${ }^{36}$. It provides that parties and their representatives, based on relevant evidence, have the right to ask judges to withdraw if the judges commit ex parte contact. With the introduction of the new rule, some judges are finding more hidden ways to engage in ex parte contact, which may make it difficult for a party to prove the existence of such contact.

Non-discrimination

33 Article 10 of the Code requires that judges treat parties and other participants in the litigation equally, should not show any discrimination in language and in deed. Furthermore, a judge has the duty to stop and correct participants in litigation should they use any discriminatory language or act in a discriminatory fashion. In addition, the Code explains that a judge should be fully aware of the possible differences between the parties due to their race, ethical beliefs, sex, profession, religious beliefs, education, health and place of residence. Judges must ensure that all parties can exercise equally and fully their procedural as well as substantive rights.

In practice, discrimination is mainly reflected in local judicial protectionism (LJP) as discussed earlier. It is a weak point of the Code that it does not refer to LJP directly, which perhaps is due to the complicated nature of LJP, being entangled as it is with political as well as economic issues. 
Principle 2: enhancement of judicial efficiency

Impartiality and efficiency have been targeted as the two pillars of the courts' work in the new millennium. With respect to judicial inefficiency, the most apparent manifestation is the delay in the delivery of judgments. Some commercial cases continue for years without court decisions and, when the decisions are made, the parties involved in the cases may have gone bankrupt, or illegally transferred their property, which makes enforcement impossible. Some Chinese people have stated that they do have the money to bring a lawsuit to a court, but do not have the time to wait for delayed proceedings (dadeqi guansi, dan dengbuqi). Thus, it is a trend for companies to settle disputes outside court for reasons of efficiency. For individual citizens, the tragedy that can be caused by a court's inefficiency can also be alarming. In a case of no great complexity concerning state compensation, a female farmer was pushed from one court to another. The case ran for four years and during this period she received seven different court rulings ${ }^{37}$. In another small debt dispute case, proceedings lasted seven years and the various courts involved rendered eight judgments ${ }^{38}$.

In responding to the most common problems in China, the Code addresses the efficiency issue from four perspectives. It first requires that judges should not delay in handling cases because of their schedules for private matters (Art. 18). Secondly, judges should follow strictly the time limit provided by law to promptly register, hear a case, and deliver judgment (Art. 19). Thirdly, judges should pay reasonable and sufficient time to all cases assigned to them. They should pay enough attention to save time for the parties, attorney and defendants and should work efficiently with other judges and judicial officers (Art. 20). Finally, judges should supervise parties to a case to ensure that they follow litigation procedure and time requirements (Art. 21).

The main reasons for the lack of efficiency are twofold ${ }^{39}$. Firstly, many of the delays and difficulties are due to weak conceptions of time, and the incompetent and bureaucratic way of handling cases still used by Chinese judges. It is no exaggeration to state that efficiency is a somewhat new concept for most Chinese judges. Secondly, some systems provided in Chinese law result in inefficiency. The retrial system provides a good example. According to Art. 177 of the Civil Procedure Law, if the president of a court finds some definite error in a legally effective judgment or order of his court and deems it necessary to have the case retried, he should refer it to the judicial committee for decision. On the same ground, the Supreme People's Court has the power to bring a case for trial by itself or direct a lower court to hear a retrial. Since the law does not provide time limits for the retrial of a case, in practice, a case can be retried a number of times.

Principle 3: keep clean and honest in performing duty

This principle tackles the ethical issue from an economic angle. The Code sets up the Five No's:

39 1) judges should neither directly nor indirectly use their position to obtain improper benefits for themselves, their relatives or others (Art. 23);

40 2) judges should not accept entertainment, goods, etc., offered by the parties to a case, their representatives and defenders (Art. 24);

41 3) judges should not become involved in commercial activities or other economic activities that may cause public doubt as to the integrity of judges (Art. 25); 
42 4) judges should make appropriate arrangements for their personal affairs and should not deliberately disclose their position as judge in order to obtain special attention, and should not use the reputation and influence associated with the position for private interests either for themselves, their relatives or others (Art. 26);

43 5) judges should not be part-time lawyers, legal advisors for companies, governmental institutions or individuals and should not provide legal advice or legal opinions on a pending case to parties (Art. 28).

44 It is true that most Chinese condemnation of judicial corruption is related to the abovementioned Five No's. Over the years, it has become a serious problem that judges accept money, gifts and invitations for meals from both the plaintiff and defendant. Some Chinese say "the judge's big hat has two brims, after eating with the plaintiff, eat with the defendant; after he has finished eating with them both, he says that the legal system is not perfect" ${ }^{\prime 4}$. Even though Chinese laws, such as the Civil Procedure Law and the Law on Judges, and several orders of the SPP ${ }^{41}$, prohibit judges from misusing power for private gain, in reality this serious misconduct has only intensified and resulted in many "human feelings cases" (renqing an), "relationship cases" (guanxi an), and "money cases" (jinqian an) ${ }^{42}$. The President of the Supreme People's Court once indicated that the ethical level of Chinese judges as a whole "is not matched with the requirement of professionalism, and it is difficult to resist money worship, hedonism, a privileged mentality and other corrupt thoughts" ${ }^{33}$; some judges "forge legal documents, use cases for private gain, use power for private gain, distort laws for private gain, which have made a very bad impression in society" 44 .

The Code also lays down standards for the judge's family. The lifestyle of judges and their family should be compatible with their position and income (Art. 27). A result of China's economic reforms is the new wealth and potential for a life of luxury. A judge's normal income is almost the same as that of a civil servant, which offers a good life, but does not make them as rich as top commercial lawyers or successful entrepreneurs. It is true that some Chinese judges are disturbed to see that some lawyers have become rich so quickly, while they are far behind. Thus, they look for ways to gain economic benefits. Some Chinese estimate that the grey (illegally gained) income, has made the average income of Chinese judges higher than that of lawyers ${ }^{45}$. In Chinese culture, people are fond of comparing status, rank, income, lifestyle, etc., which generates much unnecessary dissatisfaction with one's own life. As a matter of economic progress, material life has improved for most Chinese in recent years: this makes it possible for people to choose a profession more in accordance with their own personal wishes than from the pressure to survive. As part of legal education, one should be taught that if one chooses the judiciary as a profession, one bears high social responsibility and one's lifestyle must fit this profession. Judges should realise that even a few judges' corrupted behaviour could cause public distrust of the judiciary as a whole. On the other hand, it is also the responsibility of the government to ensure that judges receive sufficient income to maintain a good lifestyle. It is reported that some courts, especially at basic level, could not even guarantee that judges receive their salary on time. Under such circumstances how could one expect judges to be clean and honest in performing their duty?

Principle 4: observance of judicial decorum

In general terms, the Code calls for judges to respect all judicial etiquette, keep up a good appearance and civilised behaviour and to guard the authority of the courts and 
the good image of judges (Art. 31). In more concrete terms, the Code requires judges to respect the human dignity of the parties. They should earnestly and patiently listen to the parties to a case in expressing their views and should not interrupt or stop them at will unless for the reason of maintaining court order. In addition, judges should use standard and civilised language and should not admonish or apply improper words to the parties (Art. 32). In the courtroom, judges should follow courtroom rules and supervise all persons there to do the same. Judges must wear robes or a judge's uniform and badge, be in the courtroom on time and not leave early, nor go in and out during court session; and must concentrate on the trial and do nothing irrelevant to the trial (Art. 33).

Judicial decorum is fundamental for the judicial profession. Some Chinese judges are extremely short of training in this respect. For instance, it has happened that a judges say to a rich party to a case, "you have so much money, paying one million in compensation is no problem for you". Sometimes before judgment is delivered, a judge tells a party: "you will definitely lose this case"; or a judge says arbitrarily to a party: "what you said is not correct". In settling divorce cases involving third parties, some judges are too flippant, for example saying to the man that "it is not a big problem if you have a lover, but make sure that your wife does not know and make problems". Some judges have been seen smoking, drinking tea and using mobile phones, as well as actually leaving the courtroom, while the trial is in progress ${ }^{46}$. Some judges abuse their privileged position and power, criticising and rebuking parties, etc. Such conduct provides a people's court equivalent to government offices in feudal China (yamen ${ }^{47}$.

The improper use of words is not just a language puzzle; it reflects the depleted standards of the profession. The Code's provisions on judicial decorum remain too general: detailed, concrete and complete standards need to be developed. Moreover, training of judges in this aspect needs to be strengthened. A good image and authority of the judiciary cannot be established without the civilised and professional behaviour of judges.

Principle 5: to strengthen self-improvement

Compared to the other principles, this one sets up higher moral and behavioural standards for judges. It outlines an ideal judge: holding rich social experiences and profound understanding of social reality; having belief in their devotion to their duty, judging cases according to law, upright and never stooping to flattery and not seeking private gains; having the intuitive knowledge of punishing evil and encouraging good, enhancing justice; having the character of fair-mindedness, kindness, modesty and prudence; and enjoying a good personal reputation (Art. 35). In their daily lives judges should exercise strict self-discipline, be cautious in their words and deeds, have high moral values and be good models of social morality and family virtue (Art. 37).

Article 36 states that it is a judge's right as well as duty to have educational training, to foster a good learning atmosphere, to study legal theory in depth, and to advance their judicial skills in presiding over trials, judging evidence and writing judicial documents.

51 One may think that at present Principle 5 is more a far-reaching ideal than a reality for many Chinese judges. However, setting up high standards in the Code is definitely needed for enhancing and improving the professionalism of judges and is essential for the deepening of judicial reform. Unlike other principles, such as independence and neutrality, the realisation of which depends on many elements, some of which are beyond the control of courts and judges, self-improvement standards can be reached by 
serious commitment to the judicial profession. Consequently, education in this should be intensified.

Principle 6: limitation of extra-judicial activities

This principle lays down rules on what judges should not do, what they could do but must be cautious in doing and what they can do within the prescribed limitations.

First, let us consider what judges should not do. Judges must stop harmful hobbies and conduct, which are incompatible with the public interest, public order, social public morality and good customs and which may affect the good image of judges and their ability to fulfil judicial functions fairly (Art. 39). Judges should not be members of cult organisations, commercial organisations or organisations that may make profits by using a judge's influence (Arts. 41 and 43).

Secondly, there are activities which judges could do but must be cautious in pursuing. Article 40 states that judges should be cautious in going to places of entertainment, in making friends and in treating and contacting parties to cases, lawyers and other people in order to prevent generating public doubt about the fairness and integrity of judges and to prevent possible worries and embarrassment in exercising their duties. Moreover, when publishing articles or being interviewed by the media, judges should exercise caution, should not make inappropriate comments on specific cases or parties to the cases and should try to avoid causing public doubt about judicial impartiality due to such inappropriate words or deeds (Art. 45).

Thirdly, there are things which judges can do, but subject to certain restrictions. As a general rule, judges who are involved in extra-judicial activities should not allow these activities to interfere with their performance of their judicial duties. They should also avoid creating reasonable suspicion in the public domain about the judge's impartiality and integrity, and avoid damaging public confidence in the courts (Art. 38). In conducting extra-judicial activities, judges should not disclose or use unpublished judicial information, commercial secrets, personal secrets or other unpublished information that they have obtained during trial cases (Art. 42). Judges may participate in academic research or other social activities that are conducive to legal development and judicial reform. However, such activities should be based on the conditions that they must be legal, not hinder judicial impartiality and authority and not affect judicial work (Art. 44).

It seems necessary to discuss the scope of extra-judicial activities. The Code's provisions specifically mention entering places of entertainment, making friends, contact with parties to a case and their lawyers, participating in academic activities, joining cult organisations and profit-making social organisations, publishing articles and accepting interviews with the media. The Code also mentions in general terms "various extra-judicial activities" and "harmful hobbies and conduct". Obviously, the Code does not provide an exhaustive list of what may be "extra-judicial activities". In reality, the most common problems concerning a judge's extra-judicial activities may not be separated from a judge's judicial activities, such as going out for dinners with people who are parties to cases, actively making friends with business people and giving interviews to newspapers and TV on pending cases. By implementing the Code, judges should rethink their behaviour as a judge rather than an ordinary citizen.

57 In addition, there are also some practices which are not mentioned by the Code but are conducted by judges and may cause public suspicions of judicial propriety. For instance, based on investigation of people's tribunals in rural China, a researcher has 
reached the conclusion that judges working at the tribunals displayed two faces. On the one hand, they functioned as judges by settling various disputes and, on the other, they participated in law enforcement of local governments, such as directly taking part in the collection of bank loans ${ }^{48}$. Local judges are also sometimes called to join popular legal education activities (pufa), develop and promote family planning policy, etc. Direct involvement in activities that belong to governmental institutions by judges reflects the influence of legal instrumentalism, and undermines judicial independence. Thus, such activities should also be considered extra-judicial activities and should be limited or prohibited.

Since the imposition of limits upon extra-judicial activities is a rather new phenomenon for the Chinese judiciary, and since opportunities for such activities are increasing, judges must take the issue seriously, and courts should also protect judges from engagement in activities that belong to executive branches.

Implementation of the Code of Conduct

The Code provides some general implementation rules. Article 17 states that if a judge, based on the information he has obtained, is sure that other judges have possibly or actually violated judicial ethics, the result of which has been to affect judicial impartiality, the judge should report the matter to the relevant organs. Article 29 requests judges to report their property honestly according to law. However, these reporting systems need to be concretised.

Most of the principles in the code are formulated in a general manner. It is indispensable that interpretation and commentaries are made by the SPC constantly in order to give judges direct guidance. For instance, as to extra-judicial activities, Article 45 provides that "judges should be cautious when publishing articles or being interviewed by the media... to prevent reasonable public doubt as to judicial impartiality due to a judge's improper words and actions." Could this Article prevent a judge from publishing romantic or detective novels that are closely related to judicial work? The Internet is becoming a widely used platform for all industries. On a web site $^{49}$, one can find Mr. Xxx, a senior judge at the Higher Court in Shanghai, an author, Deputy Chief Editor of the Internet journal Fayuan (The Court) and a member of the Authors' Association in Shanghai. This judge, besides working in court, has long been involved in writing novels. This website published his four novels: "Judges' Thought", "Judges' Anxiety", "Judges' Adventure" and "Judges in Danger". It is debatable whether a judge who is active in publishing judiciary-related literature, which is a type of extrajudicial activity, is behaving properly under the Code. Authoritative commentary on this can only be given by the SPC.

61 In addition, the education and training of judges under the Code need to be intensified. Many types of behaviour which are prohibited in the Code were, and remain, common practice. Since these types of behaviour have become habitual in much judicial practice, it is not easy to correct them. For instance, it seems part of a cultural phenomenon for judges to accept money, goods or invitations to have dinner with the parties or people connected with parties. In some cases, judges may not like it but are compelled to do so by their working environment. It is said that judges sometimes invite each other to dinners intending to use such an opportunity to arrange for a judge to meet one of the parties to a case. If a judge does not accept an invitation first time round, he may be considered to have disrespected the inviter; if he rejects it a second time, he will be treated as unreasonable; and if he rejects it a third time, he is deemed 
to be an outsider and will be isolated from his colleagues ${ }^{50}$. Chinese society is often described as full of human feeling and connections. It is therefore a tremendous challenge for judges to keep their distance from such cultural and social phenomena while trying to uphold their professional ethics.

The Code should be viewed as a professional guideline for fostering responsible judges. Consequently, judges should be encouraged to follow the Code conscientiously. In essence, ethical issues are regulated by moral standards. To improve judicial ethics in China largely depends upon the attitudes of the judges. However, it is always the case that some judges break rules to a remarkable degree, for which disciplinary punishment or even their exclusion from the judiciary seems inevitable. In dealing with such cases, strict procedures need to be applied.

Lastly, the implementation of the Code needs not only the co-operation of the judges but also institutional changes that enable judges to behave as intended in the Code. Such institutional changes cover a wide range of aspects. For instance, the system of selection and promotion of judges needs to be redesigned. Candidates should meet not only the formal requirements, such as holding a law degree and passing the national judicial examination, but also other conditions, including fine personal traits, such as being thoughtful, humane and loyal to the highest aims of the profession. It is advisable that psychological tests should be applied to make selections from among potential candidates. Such selection mechanisms could help to ensure that the door of the judiciary would open only to the most highly qualified candidates. It would also be worthwhile weighing up the pros and cons of the present judicial committee system, which allows members of the committee to decide difficult and significant cases without hearing the case. This system restricts the independence of trial judges. The Code is absolutely right to highlight the significance of independence, neutrality and other basic principles of the judicial profession. However, true judicial independence cannot be guaranteed without institutional support. Some Chinese scholars have been calling for legislative efforts to entitle courts and judges to exercise judicial power independently subject to international standards ${ }^{51}$, but for the time being the political "go ahead" for such proposals remains unlikely.

IMPROVEMENT of the ethics of Chinese judges is among ongoing efforts at judicial reform. Without substantial upgrading on this matter the Chinese judiciary would not be able to strengthen its authority, which is needed for the balance of powers. A weak, and to a certain extent distrusted, judiciary would not be able to bear the function of an independent administration of justice. Xiao Yang, the President of the Supreme People's Court, has stated that "the overall professional quality of Chinese judges has not been high". ${ }^{52}$ Recognition of this shortcoming should lead to consistent and effective endeavours on the part of the Supreme People's Court and all judges.

Some have tried to roughly categorise Chinese judges into four groups ${ }^{53}$. The first group includes the excellent model judges. They possess both a high professional capacity and a strong commitment to social justice. The second group consists of popular judges. Under all kinds of pressures, they do their best to maintain the good image of the courts; they handle most cases fairly and are cautious in judicial practice. However, they are sometimes influenced by their social environment and have acted in a manner incompatible with judicial ethics. This group could be considered as judges shaped by their environment. Under a reasonable rule of law and a more conducive social environment, they could be good judges. The third group is slack judges. For them, 
being a judge is a means of supporting their family. Their competence in handling cases is adequate, but they lack any real consciousness of ethical issues. Prompted by private interests and personal relationships, they could behave in ways contrary to a judge's intuitive knowledge and may even fail to behave scrupulously and honestly in the performance of their duty. The fourth group is corrupt judges. They lack professional responsibility, are selfish, take no notice of judicial ethics and violate professional disciplines and the law. Consequently, they are the main cause of the bad image of the judiciary.

We could assume that only a small percentage of judges belong to the last group, though the damage they cause to public trust in the judiciary is immense. The first group of judges is, sadly, also small in number. Occasionally, stories about such model judges are reported in the newspapers; indeed, these stories can be very moving ones in the Chinese context. The majority of judges fit into the second and third groups. They function in a typical Chinese environment and their movement in good or bad directions depends very much upon the "broader environment". To guide this large group of judges, education and training in ethics is crucial.

It has been observed that in the Western world "the responsibilities of the judge were originally framed in terms of a divine paradigm. The pattern for the judge was the judgement exercised by the gods or God. Only at this very high level did it seem possible to attain the incorruptibility, the unchangeability, and the impartiality that human beings believed that judges should have" ${ }^{54}$. China does not have such a tradition. In modern times, it also seems unrealistic to impose such a belief on Chinese judges and the Chinese public. The communist ideology concerning the ideal judge has also become less and less convincing. It seems wise and realistic to stress the professional responsibility of judges from an ethical point of view. Thus, one can be certain of the significance of the promulgation of the Chinese Code for Judges. However, as indicated earlier, the enforcement of the Code is the final goal and this is a more troublesome matter. As the levels and frequency of public condemnation of the misconduct of judges show an escalating trend, an improvement in judicial ethics has to be and is an inevitable and vital component of any judicial reform.

\section{NOTES}

1. The full text of the Code was published in Renmin fayuan bao (People's Courts Daily), October 19th 2001.

2. Jing Hanchao and Lu Zijuan, Shenpan fangshi gaige shilun (Practical Analysis of the Reform of the Trial Method), Renmin fayuan chubanshe, 1997, p. 3.

3. Cai Dingjian, "Development of the Chinese Legal System since 1979 and its Current Crisis and Transformation", Cultural Dynamics, Vol. 11, No. 2, 1999, p. 154. 
4. The Hon. Mr Justice Thomas, Judicial Ethics in Australia, The Law Book Company Limited, Sydney, 1988, p.8.

5. The Germany Judiciary Act, Documents on Politics and Society in the Federal Republic of Germany, INTER NATIONES, e.V., Bonn, 1993.

6. For the Code of Conduct for United States Judges, see www.fjc.gov. Ethical Principles for Judges, Canadian Judicial Council, Catalogue Number JU 11-4/1998 E, ISBN 0-662-27376-1, available from www.cjc.gc.ca. The Code of Judicial Ethics adopted by the Italian Association of Judges and Public Prosecutors.

7. For instance, the Code of Conduct for United States Judges contains 7 Canons, namely, integrity and independence of the judiciary; avoid impropriety and appearance of impropriety in all activities; perform the duties of office impartially and diligently; extra-judicial activities should be limited to improve the law, the legal system, and the administration of justice; extra-judicial activities should minimise the risk of conflict with judicial duties; regularly file reports of compensation received for law-related and extra-judicial activities; refrain from political activity. 8. Margaret Y. K. Woo, "Law and Discretion in Contemporary Chinese Courts", in Karen G. Turner et al. eds., The Limits of the Law in China, University of Washington Press, 2000, p. 173.

9. Wang Liming, "Sifa Gaige Yanjiu" (Research on Judicial Reform), Peking, Falü chubanshe, 1999, p. 61.

10. Ibid, pp. 61-62.

11. Li Xiaolin, "Guanyu sifa tizhi gaige de shexiang" (Some Thoughts on Judicial Reform), Zhongguo lüshi (Chinese Lawyer), 1999/4, p. 7.

12. Cai Dingjian, op. cit., p. 162.

13. He Weifang, "Xingxun bigong weinaban" (Why Torture), in his book

Sifa de linian yu zhidu (Judicial Conception and System), China

University of Politics and Law Press, 1998, p. 291.

14. Fortunately, this case was corrected under the persistent efforts of a lawyer, and the fair judgment of the Heilongjiang Provincial Higher Court. For six years the two suspects had no freedom and the caused tremendous grief to their family. When the two suspects requested compensation from the intermediate court and the prosecution office which wrongly handled the case, a relevant person in the court even said: "why do you not go to the public police office? If they did not catch the wrong persons, we wouldn't have wrongly handled the case"; see $\mathrm{Li}$ Weijun and Wang Hongying, "Yige yu sishen sanci cajian de 'siqiu'” (A Convict Who Was Sentenced to Death Three Times), Fazhi yu xinwen (Law and News), December 2001, pp. 37-38.

15. According to this article, the police office (at county level) gave the police "the task to amerce"? and individual police could deduct $30 \%$ of the fine. See You Xia, "Nongnu beibi zisha, gonganiu gaipeiduoshao" (A Farmer's Girl Was Compelled to Commit Suicide, How Much Should the Police Office Pay), in Minzhu yu fazhi (Democracy and Legal System), No. 5, 2000, pp. 21-23. Cases were reported that even members of the People's Congress were beaten up, searched, or illegally detained by police. See a few articles in Minzhu yu fazhi, No. 6, 2000, pp. 4-7. 
16. Li Lin, "Organization and Power of Police in China", in Liu Hainian, et al. eds., Human Rights and Administration of Justice, Collected Papers from the Chinese-Danish Symposium on the Protection of Human Rights in Judicial Work (Chinese and English), China Legal System Publishing House, 1999, p. 19 and p. 152.

17. See Chutian dushibao (Chutian City Newspaper), April 27th 1999 , quoted in Fan Zhongxin, "Sifa fubai de leixing yu zhidu zhuyin fenxi" (The Types of Judicial Corruption and Analysis of System Element), in Xin Chunying et al. eds., Yifa zhiguo yu sifa gaige (Rule of Law and Judicial Reform), Peking, Zhongguo fazhi chubanshe, 1999, p. 113. 18. Li Xiaolin, op. cit., No. 4, 1999, p. 7.

19. Wang Liming, op. cit., p. 49.

20. Jing Hanchao, "Zhongguo wenhai chuangji sifa gaige" (Chinese Culture "Clash" with Judicial Reform), Zhongguo lüshi, No. 6, 2001, p. 21.

21. See the United Nations Basic Principles on the Independence of the Judiciary, A/RES/40/32, November 29 1985.

22. See Margaret Y.K. Woo, "Adjudication Supervision and Judicial Independence in the P.R.C.", The American Journal of Comparative Law, Vol. 39, 1991, pp. 95-119; Hikota Koguchi, "Some Observations About 'Judicial Independence' in Post-Mao China", in R.H.Folsom and J.H.Minan eds., Law in the People's Republic of China, 1989, pp. 189-197; Marie Seong-Hak Kim, "A Distant Premise: Judicial Independence in the People's Republic of China", in Korean Journal of Comparative Law, Vol. 24, 1996, pp. 17- 42; Liao Kuangsheng, "Independent Administration of Justice" and the PRC Legal System, in Chinese Law and Government, Vol. XVI, Nos. 2-3, 1983, pp. 123-152; and Xin Ren, Tradition of the Law and Law of the Tradition, Law, State, and Social Control in China, Greenwood Press, 1997, pp. 47-63.

23. See "Renmin Fayuan wunian gaige gangyao" (Five-year Program to Reform the System of People's Courts), edited by the research department of the Supreme People's Court, Renmin fayuan chubanshe, 2000.

24. Cai Dinjian, op. cit., pp. 149-151.

25. Nanfang zhoumo (Southern Weekend), December $5^{\text {th }} 2002$.

26. Frances Kahn Zemans, "The Accountable Judge: Guardian of Judicial Independence", in Southern California Law Review, Vol. 72, Nos. 2-3, 1999, p. 654.

27. Li Hao, Minshi shenpan zhongde tiaoshen fengli (Separation of Mediation and Trial in Civil Trial), in Jiang Ping and Chen Guiming eds., Minshi shenpan fangshi gaige yu fazhan (Reform and Development of the Civil Trial Method), Zhongguo fazhi chubanshe, 1998, p. 203.

28. For details, see Margaret Y. K. Woo, "Law and Discretion ...", op. cit., p. 174.

29. See Li Hao, op. cit., pp. 208-210.

30. Ibid., p. 203.

31. Ibid., p. 210. 
32. Stanley B. Lubman, Bird in a Cage Legal Reform in China After Mao, Stanford University Press, 1999, p. 274. See also Margaret Y. K. Woo, "Law and Discretion ..." op. cit., p. 174. She observed that "While the procedural codes also require that the contents of a mediated agreement shall not violate the law, the process of mediation has no formalities and is to be conducted according to the judge's innate sense of right and wrong. Indeed, the procedure for mediation allows the courts to reach compromised and individualized, but perhaps not always consistent, decisions."

33. Jian Hanchao and Lu Zijuan, "lun jinzhi danfang jiechu yuanzi" (Discussion of the Principle of Prohibition of Ex Parte Contact), Renmin sifa (People's Judiciary), 1998/10, p. 4.

34. Ibid.

35. Ibid., p. 5.

36. The full text is contained in the "Five-year Program ..." op. cit., pp. 118-120.

37. Li Jian and Xie Wenchao, "Yiwei nongfu yu xian gonganju de malasong guansi" (A marathon lawsuit between a female farmer and a county public security bureau), Minzhu yu fazhi (Democracy and Legal System), No. 3, 2000, pp. 20-22.

38. Li Xianhong, “Qinianbashen nanduanyian” (Seven years and eight judgments, it remains difficult to decide a case), Minzhu yu fazhi (Democracy and Legal System), No. 9, 2000, p. 17.

39. Jiang Huiling summarised eight main problems on judicial efficiency. See "Tigao Sifa Xiaolu de yiwu” (Obligation to enhance judicial efficiency), Falü shiyong (National Judges College Law Journal), 2001/6, p. 4.

40. Cai Dingjian, op. cit., p. 149. Cases where judges misuse their power in return for personal benefits have been occasionally reported in press. For example, a judge at Zhenhai Basic Court accepted a few thousand yuan from a lawyer for the defence and dined with the lawyer on a few occasions and then decided to release the court's decision to seal up the accused's property. This resulted in enabling the accused to sell his property immediately. Even though the plaintiff won the case, the judgment could not then be enforced, since the accused had no property with which to pay the plaintiff. Chen Hong, 'Revealing the inside story of a case', Minzhu yu fazhi (Democracy and Legal System), No. 14, 2000, pp. 8-11.

41. See Article 44 of the 1991 Civil Procedure Law; Article 32 of the Law on Judges (amended in 2001); Article 2 of the Several Provisions concerning Strictly Following the Withdrawal System by Judges, issued by the Supreme People's Court in January 2000; The Several Opinions of the Supreme People's Court on Carrying out the Central Communist Party Document "Decisions concerning Further Strengthening of Judicial Cadres Force" and "Building up High Professional Judges”. The two documents are contained in the book, "Five-year Program ...", op. cit., pp. 146-157.

42. Guo Daohui, "Shixing sifa duli yu yizhi sifa fubai" (Implementation of Judicial Independence and Control of Judicial Corruption), in Xin Chunying et al. eds., p. 92. 
43. Xiao Yang, "Five-year Program to Reform the System of People's Courts", in the "Five-year Program ...", op. cit., p. 59.

44. Xia Yang, Zuigao renmin Fayuan Gongzuo Baogao (Working Report of the Supreme People's Court), March 2003. The Report is contained in "Five-year Program ...", op. cit., p. 215.

45. This is based on my interviews with judges, lawyers and scholars in 1999 and 2001.

46. These phenomena are mentioned in an article written by a Chinese judge. The article is contained in an unpublished collection of papers written by Chinese judges on judicial conduct and ethics. On file with the author.

47. Yan Junxing, "Sifa Gongzheng de Jiazhi Neihan yu zhidu baozhang" (The connotation of Judicial Fairness and Institutional Guarantee), in Xin Chunying et al. eds., op. cit., pp. 229-230.

48. Xiaoli Zhao, The Two Faces of the People's Tribunals in Rural China, Perspectives, Vol. 3, No. 4, 2003, http://www.oycf.org/Perspectives/16-033102/ two-faces.htm.

49. http://www.law999.net/story/wenyuan1.jsp

50. A similar saying to this was told to the author by local judges in Wuhan and Beijing in 1999 and 2001 respectively when the author participated in judges' training programmes.

51. See several articles published in the book, Xin Chunying et al., op. cit.

52. Xiao Yang, "Program Designed to Promote the Reform of the System of People's Courts", Zhongguo falü (China Law), No. 1, 2000, p. 55.

53. One article in the book, supra note 47 , discussed this in detail.

Similar expression was also given to the author by a few judges in 2001 .

54. John T. Noonan et al. eds., The Responsible Judge, Readings in

Judicial Ethics, Praeger, 1993, p. xiv. 